\title{
PENGUATAN IDENTITAS NASIONAL INDONESIA MELALUI PERENCANAAN PEMBANGUNAN BERBASIS LEMBAGA KEMASYARAKATAN
}

\author{
ACHYAR HANIF SIREGAR \\ achyarhanif@gmail.com \\ Badan Perencanaan, Penelitian dan Pengembangan Provinsi Kepulauan Riau
}

\begin{abstract}
ABSTRAK
Indonesia adalah negara yang memiliki identitas nasional yang terwujud karena adanya ribuan pulau yang didiami oleh bermacam-macam suku bangsa dengan beragam bahasa yang tertutur, enam agama yang resmi dianut, serta keberagaman lainnya yang memiliki kekhasan masing-masing. Identitas nasional Indonesia seharusnya bisa menjadi potensi yang dimanfaatkan untuk mengatasi permasalahan-permasalahan bangsa saat ini seperti jumlah pengangguran di Indonesia yang mencapai 9,77 juta orang pada Agustus 2020. Namun, identitas nasional Indonesia masih rentan terhadap konflik sosial horizontal Suku, Agama, Ras, dan Antar Golongan (SARA). Tujuan penelitian ini adalah mengidentifikasi identitas nasional Indonesia dan menganalisis penguatannya melalui perencanaan pembangunan berbasis Lembaga Kemasyarakatan.
\end{abstract}

Kata Kunci: Identitas Nasional, Perencanaan Pembangunan, Lembaga Kemasyarakatan

\begin{abstract}
Indonesia is a country that has a national identity that is realized because of the thousands of islands inhabited by various ethnic groups with various spoken languages, six officially embraced religions, and other diversity that have their own uniqueness. Indonesia's national identity should be a potential that can be utilized to solve nation's current problems, such as the number of unemployed people in Indonesia which reached 9.77 million people in August 2020. However, Indonesia's national identity is still vulnerable to horizontal social conflict of ethnicity, religion, race, and groups. This research purpose is to identify Indonesia's national identity and analyze its strengthening through development planning based on Social Institution. The research method used is literature study. The result shows that efforting of strengthening Indonesia's national identity through development planning based on Social Institution can be carried out through increasing the leadership capacity of the Rukun Tetangga and Rukun Warga, reforming the nature of Customary Institutions, focusing on Community Empowerment Institutions with local wisdom, and eventing the Karang Taruna documentation award. Social Institution can be an ideal container because it has the advantage as the closest institution to communities throughout Indonesia. Social Institutions that produce participatory, tolerant, empowered, and innovative societies which are considered to become one maximum unit in strengthening Indonesia's national identity.
\end{abstract}

Keywords:National Identity, Development Planning, Social Institution 


\section{PENDAHULUAN}

\section{Latar Belakang}

Dalam bukunya yang berjudul The Power of Identity (Kaelan, 2013:316) Manuel Castells mengutip pendapat Robert de Ventos yang mengemukakan teori perihal lahirnya identitas nasional. Robert de Ventos berpendapat, identitas nasional sebuah bangsa merupakan hasil dari interaksi historis dari beberapa faktor. Adapun faktor-faktor tersebut yaitu: faktor primer, faktor reaktif, faktor penarik, dan faktor pendorong. Berkaca pada faktor primer yang meliputi di dalamnya perihal teritorial, agama, bahasa, etnisitas, dan lain sebagainya, bisa dikatakan bahwa Indonesia memiliki identitas nasional yang terwujud karena adanya ribuan pulau dalam suatu wadah Negara Kesatuan Republik Indonesia (NKRI) yang didiami oleh bermacammacam suku bangsa dengan beragam bahasa yang tertutup, enam agama yang resmi dianut, serta keberagaman lainnya yang memiliki kekhasan masing-masing. Segala keanekaragaman itu kemudian meleburkan diri menjadi Bangsa Indonesia. Peleburan menjadi satu kesatuan itu tidak membuat keberagaman menjadi luntur atau hilang. Karena itu kemudian muncul slogan Bhinneka Tunggal Ika.

Faktor primer yang dimiliki bangsa Indonesia sebagai identitas nasional seharusnya bisa menjadi potensi yang dimanfaatkan untuk mengatasi permasalahan-permasalahan bangsa saat ini, salah satunya mengatasi krisis ekonomi akibat dampak dari pandemi Coronavirus Disease 2019(Covid-19) yang menyebabkan jumlah pengangguran bertambah. Berdasarkan data yang dimiliki oleh BPS/ Badan Pusat Statistik, ada sebanyak 9,77 juta orang pengangguran di Indonesia per Agustus 2020. Menurut Suhariyanto, Kepala BPS, jumlah tersebut telah mengalami peningkatan sebanyak 2,67 juta jika dibandingkan dengan jumlah pengangguran pada tahun sebelumya. Menurut beliau juga dalam bukunya Kurniati (2020), pertambahan itu salah satu penyebabnya adalah adanya pandemic Covid-19. Belum ada tanda-tanda positif bagaimana Indonesia dapat memanfaatkan penguatan identitas nasional untuk mengatasi hal tersebut karena identitas nasional Indonesia masih rentan terhadap konflik sosial horizontal Suku, Agama, Ras, dan Antar Golongan (SARA).

Jika bangsa Indonesia tidak menemukan cara bagaimana memperkuat identitas nasional, maka ancaman terburuk yang dapat terjadi adalah disintegrasi nasional. Peran aktif partisipasi masyarakat dapat menjadi salah satu solusi yang dilakukan oleh pemerintah guna dibina menjadi satu kesatuan yang bekerja sama memperkuat identitas nasional. Pembinaan oleh pemerintah ini disusun melalui perencanaan pembangunan dimana melibatkan mitranya yang terdekat dengan masyarakat di seluruh Indonesia yakni Lembaga Kemasyarakatan. Berdasarkan latar belakang yang telah dijelaskan, penelitian ini akan membahas"Penguatan Identitas Nasional Indonesia melalui Perencanaan Pembangunan Berbasis Lembaga Kemasyarakatan". 


\section{Tujuan Penelitian}

Berdasarkan latar belakang yang telah dijelaskan, tujuan penelitian ini adalah mengidentifikasi identitas nasional Indonesia dan menganalisis penguatannya melalui perencanaan pembangunan berbasis Lembaga Kemasyarakatan.

\section{TINJAUAN PUSTAKA}

\section{Identitas Nasional}

Secara terminologi identitas nasional adalah ciri-ciri yang melekat pada suatu bangsa, di mana ciri-ciri tersebut merupakan pembeda antara suatu bangsa itu dengan bangsa yang lainnya secara filosofis. Dengan demikian, semua bangsa di dunia ini sudah pasti mempunyai identitas masing-masing yang sesuai dengan karakter, sifat, ciri-ciri, serta keunikan yang dimilikinya. Selain itu, identitas nasional juga dipengaruhi oleh bagaimana secara historis bangsa tersebut terbentuk. Itu berarti identitas nasional sebuah bangsa tidak bisa dilepaskan dari jati diri atau kepribadian bangsa tersebut.

Kepribadian suatu bangsa sebagai identitas nasionalnya yaitu totalitas atau keseluruhan kepribadian dari individuindividu yang merupakan unsur pembentuk bangsa tersebut. Dengan kata lain, identitas nasional sebuah bangsa tidak bisa dipisahkan dari makna "Peoples Character", "National Character",dan "National Identity". Berpijak pada hal tersebut, identitas nasional Indonesia dan kepribadian bangsa Indonesia terbentuk atas unsur-unsur, diantaranya: suku, agama, ras, kebudayaan, etnis, serta karakter yang sejak awal mulanya memang sudah berbeda-beda. Oleh sebab itu, secara historis kepribadian Bangsa Indonesia mulai menjelma menjadi identitas nasional dimulai sejak Proklamasi Kemerdekaan Indonesia pada 17 Agustus 1945.
Dalam bukunya yang berjudul The Power of Identity, Manuel Castells (Kaelan, 2013:316) mengutip pendapat Robert de Ventos yang mencetuskan teori tentang identitas nasional, yaitu bahwa identitas nasional dari sebuah bangsa merupakan hasil dari interaksi historis di antara faktorfaktor yang meliputi: faktor primer, faktor reaktif, faktor penarik, dan faktor pendorong. Faktor primer meliputi: teritorial, etnisitas, bahasa, agama, dan sejenisnya. Faktor reaktif meliputi: pencarian identitas melalui memori kolektif, dominasi, serta penindasan. Faktor pendorong meliputi: pemantapan sistem pendidikan, tumbuhnya birokrasi, dan kodifikasi bahasa dalam gramatika. Sedangkan faktor penarik meliputi: lahirnya angkatan bersenjata modern, pembangunan teknologi dan komunikasi, dan juga pembangunan lainya.

\section{Perencanaan Pembangunan}

Hadiwijono dan Anisa dalam bukunya (2019:92) mengutip Moeljarto Tjokrowinoto yang mengemukakan tentang makna perencanaan pembangunan. Menurutnya, perencanaan pembangunan adalah sebuah konsep yang didalamnya meliputi dua aspek, yakni: Pertama, perencanaan pembangunan merupakan sebuah proses perumusan rencana pembangunan. Kedua, perencanaan pembangunan sebagai substansi dari rencana pembangunan. Adapun proses dari perumusan rencana pembangunan tersebut erat hubungannya dengan kegiatan bagaimana perencanaan tersebut disusun, kapan akan dimulai realisasinya, serta siapa pihak yang akan turut serta dalam proses penyusunannya. Sementara itu, substansi rencana pembangunan adalah perihal esensi atau isi dari rencana pembangunan yang telah dirumuskan dan ditetapkan. Termasuk di dalamnya tentang problem-problem utama 
serta berbagai isu yang penting untuk segera dipecahkan.

Dalam perencanaan pembangunan terdapat beberapa pendekatan salah satunya perencanaan transaktif. Suryo Sakti Hadiwijoyo dan Fahima Diah Anisa dalam bukunya (2019: 61) mengemukakan bahwa yang menjadi fokus dari pendekatan perencanaan transaktif adalah keutuhan pengalaman kehidupan masyarakat berkaitan dengan soal kebijakan yang mesti ditangani.

Dengan demikian berarti basis atau dasar dari perencanaan pembangunan tersebut adalah pengalaman riil/ sesungguhnya masyarakat. Oleh sebab itu, perencanaan tidak didasarkan pada target kalangan/komunitas anonim yang menerima manfaat. Akan tetapi penerima manfaat yang berada dalam kontak langsung dengan masyarakat yang dipengaruhi oleh keputusan. Perencanaan tersebut tidak terlalu mengacu pada analisis data serta survei di lapangan, namun lebih mengedepankan dialog dengan orang per orang. Sehingga, pihak perencana tersebut benar-benar terjun langsung ke masyarakat untuk mengantarkan sumber daya kepada mereka yang benar-benar butuh.

Hadiwijoyo dan Anisa dalam bukunya (2018:62) juga mengutip pendapat John Friedman yang menyatakan bahwa perencanaan transaktif merujuk pada evolusi dari lembaga desentralisasi yang fungsi dan peranannya membantu orang dalam melakukan kontrol pada proses sosial yang mengatur kesejahteraan mereka. Dalam hal ini perencanaan tidak dipandang sebagai kegiatan yang terpisah dari tindakan-tindakan sosial. Akan tetapi, dinilai sebagai proses yang lahir dari evolusi ide-ide yang berlangsung secara terus-menerus dalam tindakan.

\section{Lembaga Kemasyarakatan}

Dalam Permendagri Pasal 1 ayat 1 Nomor 5 Tahun 2007 perihal Pedoman Penataan Lembaga Kemasyarakatan menegaskan, Lembaga Kemasyarakatan adalah lembaga yang dibuat/didirikan oleh masyarakat sesuai dengan kebutuhannya, serta merupakan rekan/mitra lurah dan Pemerintah Desa dalam mengupayakan pemberdayaan masyarakat. Rahyunir Rauf dan Yusri Munaf dalam bukunya (2015:100) mengemukakan bahwa yang menjadi tujuan dari pembentukan lembaga kemasyarakatan ialah agar terpelihara dan terlestarikannya nilai-nilai kehidupan yang ada di masyarakat berlandaskan kekeluargaan dan kegotongroyongan. Kedua nilai tersebut adalah sendi pokok yang berlaku di dalam kehidupan bermasyarakat rakyat Indonesia. Sedangkan yang dikemukakan oleh Saparin (Rauf dan Munaf, 2015: 101) tujuan dari pembentukan lembaga masyarakat adalah dalam rangka peningkatan kelancaran terlaksananya tugas-tugas pembangunan, kemasyarakatan serta pemerintahan.

Dengan kata lain, lembaga masyarakat secara tidak langsung membantu jalannya fungsi pemerintah. Untuk itu Saparin (Rauf dan Munaf, 2015: 101) menyatakan, meski organisasi RT/RW bukanlah merupakan lembaga pemerintahan, tetapi untuk beberapa hal serta dalam batas-batas tertentu, wajib membantu aparatur pemerintahan.

Selain itu, Lembaga Kemasyarakatan juga adalah salah satu dari struktur perantara yang ada di Indonesia. Bukan saja hanya rakyat/masyarakat yang membutuhkan jembatan/perantara dengan pemerintah. Akan tetapi juga sebaliknya, pemerintah pun butuh perantara yang akan menjembataninya dengan masyarakat. 
Dengan demikian, sebenarnya keberadaan lembaga kemasyarakatan dibutuhkan oleh keduanya. Adapun dalam Pasal 5 Permendagri Nomor 5 Tahun 2007 menegaskan bahwa kegiatan dari Lembaga Kemasyarakatan bertujuan untuk mempercepat tercapainya kesejahteraan masyarakat dengan cara:

a. Meningkatkan pelayanan kepada masyarakat;

b. Meningkatkan peranan masyarakat dalam pembangunan;

c. Mengembangkan kemitraan;

d. Memberdayakan masyarakat; serta

e. Mengembangkan aktivitas lainnya yang sesuai dengan keadaan dan kebutuhan masyarakat.

f. Seperti yang tertuang dalam Permendagri, Pasal 7 Nomor 5, Tahun 2007, jenis-jenis Lembaga Kemasyarakatan meliputi:

a. LPMK, yaitu Lembaga Pemberdayaan Masyarakat Kelurahan (jika berada di wilayah perkotaan) atau LPMD untuk yang ada di wilayah desa.

b. Lembaga Adat;

c. Pemberdayaan serta Kesejahteraan Keluarga/ PKK. Baik di wilayah desa/kelurahan;

d. RT/RW;

e. Karang Taruna, dll

\section{METODOLOGI PENELITIAN}

Penelitian ini menggunakan metode studi pustaka, yaitu sebuah kegiatan/ aktivitas yang mencakup di dalamnya pencarian, membaca, kemudian memahami, serta melakukan analisis terhadap literaturliteratur dan hasil penelitian. Studi pustaka bisa juga dimaknai sebagai studi yang berkaitan dengan penelitian yang hendak dilakukan. Manfaat yang bisa diambil dari studi pustaka yaitu semakin kayanya pengetahuan serta argumentasi si peneliti perihal permasalahan sosial atau konsep penelitian yang hendak dilaksanakan.

Studi pustaka dalam penelitian ini bertujuan untuk mempelajari ide-ide orang lain dan merangsang ide-ide baru. Sebuah studi pustaka menceritakan apa yang telah ditemukan orang lain sehingga peneliti dapat mendapatkan keuntungan dari usaha orang lain. Sebuah review yang baik juga mengidentifikasi banyak hal yang tidak diketahui peneliti dan menunjukkan hipotesis untuk melakukan replikasi (pengulangan). Proses ini memberikan pengetahuan mengenai prosedur, teknik, dan desain penelitian sehingga peneliti dapat lebih fokus pada hipotesis dan mendapatkan wawasan baru.

Sumber pustaka yang dijadikan prioritas dalam penelitian ini adalah sumber yang dipandang memiliki kekuatan ilmiah dan dapat dipertanggungjawabkan, yaitu:

1) Ensiklopedi dan kamus;

2) Jurnal ilmiah;

3) Buku;

4) Makalah seminar;

5) Karya ilmiah;

6) Dokumen resmi pemerintah; dan

7) Sumber resmi lainnya.

\section{PEMBAHASAN}

\section{Identitas Nasional Indonesia}

Identitas nasional bangsa Indonesia yang ingin diperkuat pada dasarnya merupakan kegiatan yang kompleks jika dirujuk sekaligus dengan keempat faktor yakni faktor primer, faktor pendorong, faktor penarik, dan faktor reaktif. Oleh karena itu, penguatan identitas nasional yang diawali dari faktor primer dirasa lebih efektif dengan harapan akan berpengaruh pada penguatan terhadap ketiga faktor lainnya di kemudian hari. Merujuk pada faktor primer yang berupa teritorial, etnisitas, bahasa, 
agama, dan sejenisnya, maka bangsa Indonesia dapat diartikan memiliki identitas nasional sebagai berikut:

\section{Teritorial}

Pada tahun 1982, Deklarasi Djuanda diterima dan ditetapkan oleh Persatuan Bangsa-Bangsa PBB dalam UNCLOS atau United Nations Convention on the Law of the Sea. Setelah itu dikeluarkan undangundang untuk mempertegas penetapan
UNCLOS tersebut. Yaitu UU No.17 Th 1985 yang menegaskan di dalamnya bahwa Indonesia merupakan negara kepulauan. Pada tahun 2013, Muhammad Ramdhan dan Taslim Arifin dalam artikel ilmiahnya, "Aplikasi Sistem Informasi Geografis dalam Penilaian Proporsi Luas Laut Indonesia" (2013: 145), merilis luas wilayah Negara Kesatuan Republik Indonesia (NKRI) dalam tabel sebagai berikut:

Tabel 1. Luas Wilayah NKRI

\begin{tabular}{|l|l|l|l|}
\hline No & \multicolumn{1}{|c|}{ Luasan NKRI } & \multicolumn{1}{|c|}{$\mathrm{km}^{2}$} & \multicolumn{1}{|c|}{$\begin{array}{c}\text { Persentase Terhadap Wilayah Laut } \\
(\boldsymbol{\%})\end{array}$} \\
\hline 1 & Seluruh Wilayah & $8.647 .003,475$ & 100,00 \\
\hline 2 & Daratan & $1.993 .662,036$ & 23,06 \\
\hline 3 & Lautan & $6.653 .341,439$ & 76,94 \\
\hline
\end{tabular}

\section{Etnisitas}

Indonesia merupakan negara yang didiami oleh bermacam-macam suku bangsa.
Arifin,

2013:

145 .

Tabel 2. Jumlah dan Persentase Penduduk menurut Kelompok Suku Bangsa

\begin{tabular}{|l|l|l|l|l|}
\hline No & \multicolumn{1}{|c|}{ Kelompok Suku Bangsa } & \multicolumn{1}{c|}{ Jumlah } & \multicolumn{1}{c|}{ Persen } & Peringkat \\
\hline 1 & Suku asal Aceh & 4.091 .451 & 1,73 & 14 \\
\hline 2 & Batak & 8.466 .969 & 3,58 & 3 \\
\hline 3 & Nias & 1.041 .925 & 0,44 & 30 \\
\hline 4 & Melayu & 5.365 .399 & 2,27 & 10 \\
\hline 5 & Minangkabau & 6.462 .713 & 2,73 & 7 \\
\hline 6 & Suku asal Jambi & 1.415 .547 & 0,6 & 25 \\
\hline 7 & Suku asal Sumatera Selatan & 5.119 .581 & 2,16 & 10 \\
\hline 8 & Suku asal Lampung & 1.381 .660 & 0,58 & 26 \\
\hline 9 & Suku asal Sumatera Lainnya & 2.204 .472 & 0,93 & 21 \\
\hline 10 & Betawi & 6.807 .968 & 2,88 & 6 \\
\hline 11 & Suku asal Banten & 4.657 .784 & 1,97 & 11 \\
\hline 12 & Sunda & 36.701 .670 & 15,5 & 2 \\
\hline 13 & Jawa & 95.217 .022 & 40,22 & 1 \\
\hline 14 & Cirebon & 1.877 .514 & 0,79 & 24 \\
\hline 15 & Madura & 7.179 .356 & 3,03 & 5 \\
\hline 16 & Bali & 3.946 .416 & 1,67 & 15 \\
\hline 17 & Sasak & 3.173 .127 & 1,34 & 16 \\
\hline 18 & Suku Nusa Tenggara Barat lainnya & 1.280 .094 & 0,54 & 27 \\
\hline
\end{tabular}




\begin{tabular}{|l|l|l|l|l|}
\hline 19 & Suku asal Nusa Tenggara Timur & 4.184 .923 & 1,77 & 12 \\
\hline 20 & Dayak & 3.009 .494 & 1,27 & 17 \\
\hline 21 & Banjar & 4.127 .124 & 1,74 & 13 \\
\hline 22 & Suku asal Kalimantan lainnya & 1.968 .620 & 0,83 & 22 \\
\hline 23 & Makassar & 2.672 .590 & 1,13 & 20 \\
\hline 24 & Bugis & 6.359 .700 & 2,69 & 8 \\
\hline 25 & Minahasa & 1.237 .177 & 0,52 & 29 \\
\hline 26 & Gorontalo & 1.251 .494 & 0,53 & 28 \\
\hline 27 & Suku asal Sulawesi lainnya & 7.634 .262 & 3,22 & 4 \\
\hline 28 & Suku asal Maluku & 2.203 .415 & 0,93 & 22 \\
\hline 29 & Suku asal Papua & 2.693 .630 & 1,14 & 19 \\
\hline 30 & $\begin{array}{l}\text { Tionghoa (Berkewarganegaraan } \\
\text { Indonesia) }\end{array}$ & 2.832 .510 & 1,2 & 18 \\
\hline 31 & $\begin{array}{l}\text { Asing/Luar Negeri (Berkewarganegaraan } \\
\text { Indonesia) }\end{array}$ & 162.772 & 0,07 & 31 \\
\hline Total & 236.728 .379 & 100 & \\
\hline
\end{tabular}

Sumber: Na'im dan Syaputra, 2012: 9.

\section{Bahasa}

Secara umum, mayoritas penduduk daerah yang beragam untuk komunikasi Indonesia masih tetap menggunakan sehari-hari di rumah tangga. Hal tersebut bahasa digambarkan sebagai berikut:

\section{Gambar 1. Persentase Penduduk menurut Bahasa Sehari-hari Tahun 2010}

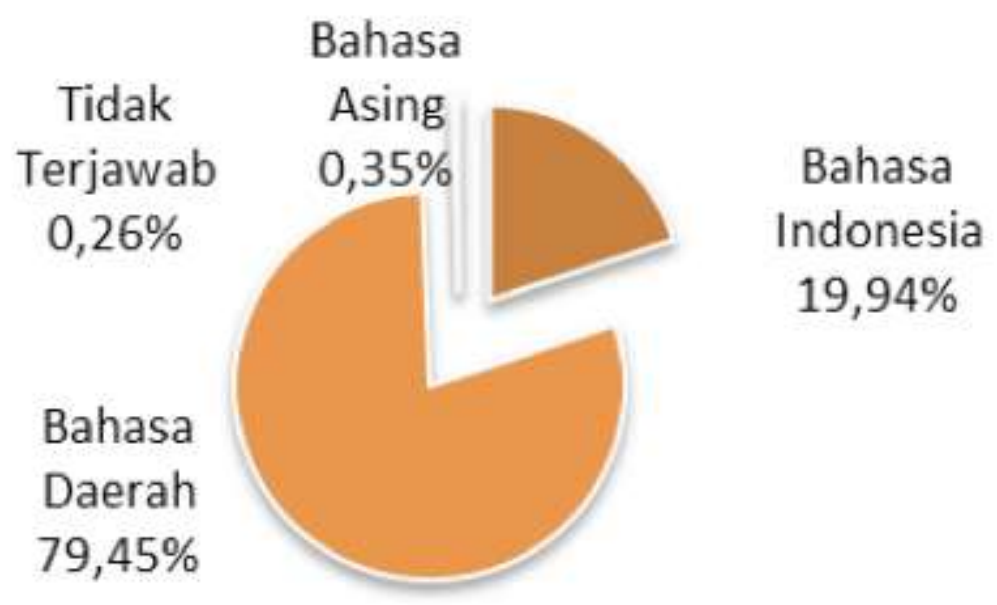

Sumber: Na'im dan Syaputra, 2012: 12.

\section{Agama}

Di Indonesia, jaminan akan kebebasan beragama dan menjalankan ibadah sesuai dengan agamanya tertuang dalam UUD
1945 pasal 29 ayat 2. Yaitu bahwa negara menjamin dan melindungi kebebasan setiap penduduknya untuk memeluk suatu agama dan melaksanakan ibadah sesuai 
dengan agama yang dianutnya tersebut. Persebaran jumlah penganut agama di
Indonesia ditunjukkan dalam tabel di bawah ini:

Tabel 3. Jumlah dan Persentase Penduduk Menurut Agama yang Dianut Tahun 2010

\begin{tabular}{|l|l|l|l|}
\hline No & \multicolumn{1}{|c|}{ Agama } & Jumlah Pemeluk (Jiwa) & \multicolumn{1}{c|}{ Persentase } \\
\hline 1 & Islam & 207.176 .162 & 87,18 \\
\hline 2 & Kristen & 16.528 .513 & 6,96 \\
\hline 3 & Katolik & 6.907 .873 & 2,91 \\
\hline 4 & Hindu & 4.012 .116 & 1,69 \\
\hline 5 & Budha & 1.703 .254 & 0,72 \\
\hline 6 & Khong hu cu & 117.091 & 0,05 \\
\hline 7 & Lainnya & 299.167 & 0,13 \\
\hline 8 & Tidak Terjawab & 139.582 & 0,06 \\
\hline 9 & Tidak Ditanyakan & 757.118 & 0,32 \\
\hline Jumlah & 237.641 .326 & 100 \\
\hline
\end{tabular}

Sumber: Na'im dan Syaputra, 2012: 10

\section{Perencanaan Pembangunan Berbasis Lembaga Kemasyarakatan}

Pendekatan partisipasi adalah pendekatan yang dipakai untuk perencanaan pembangunan yang berbasis lembaga kemasyarakatan dalam rangka pemberdayaan masyarakat. Pendekatan ini merupakan jenis dari pembangunan yang orientasinya adalah masyarakat sebagai subjek dalam pembangunan dengan menekankan partisipasinya pada segala aspek termasuk penguatan identitas nasional. Partisipasi atau keikutsertaan masyarakat tersebut sebagai wujud rasa peduli, kesadaran, juga tanggung jawabnya sebagai bagian dari warga negara. Dengan demikian berarti, masyarakat sadar bahwa aktivitas pembangunan tersebut bukan hanya menjadi kewajiban aparatur negara saja. Akan tetapi, juga diperlukan keikutsertaan masyarakat yang hendak diperbaiki kualitas hidupnya. Lembaga kemasyarakatan bisa menjadi wadah yang ideal mengimplementasikan pendekatan tersebut guna memperkuat aspek identitas nasional karena perannya dalam memberdayakan masyarakat memiliki keunggulan sebagai lembaga yang terdekat dengan masyarakat di seluruh Indonesia.

Pemerintah sebagai mitra dari lembaga kemasyarakatan memiliki kewajiban untuk membina lembaga ini sesuai dengan yang diatur dalam Pasal 23 Peraturan Menteri Dalam Negeri (Permendagri)Nomor 5 Tahun 2007 tentang Pedoman Penataan Lembaga Kemasyarakatan. Dalam menyusun strategi pembinaan lembaga kemasyarakatan guna memperkuat identitas nasional diperlukan titik fokus pada beberapa jenis lembaga kemasyarakatan saja sebagai langkah awal. Hal ini dilakukan karena dalam perubahan satu jenis lembaga kemasyarakatan akan membawa akibat pada jenis-jenis lembaga kemasyarakatan lainnya sebagaimana suatu sistem yang terintegrasi. Penguatan peran empat jenis lembaga kemasyarakatan yakni Rukun Tetangga dan Rukun Warga, Lembaga Adat, Lembaga Pemberdayaan Masyarakat, dan Karang Taruna dinilai menjadi langkah awal yang akan memperkuat identitas nasional bangsa Indonesia menyusul jenis-jenis lembaga kemasyarakatan lain nantinya. 


$\begin{array}{lcclrr}\text { Skema Penguatan } & \text { Identitas } & \text { Nasional } & \text { Indonesia } & \text { melalui } & \text { perencanaan } \\ \text { Indonesia } & & & \text { pembangunan } & \text { berbasis } & \begin{array}{l}\text { Lembaga } \\ \text { Kemasyarakatan }\end{array} \\ \text { Skema penguatan } & \text { identitas } & \text { nasional } & \text { Kebagai berikut. }\end{array}$

\section{Gambar 2. Skema Penguatan Identitas Nasional Indonesia}

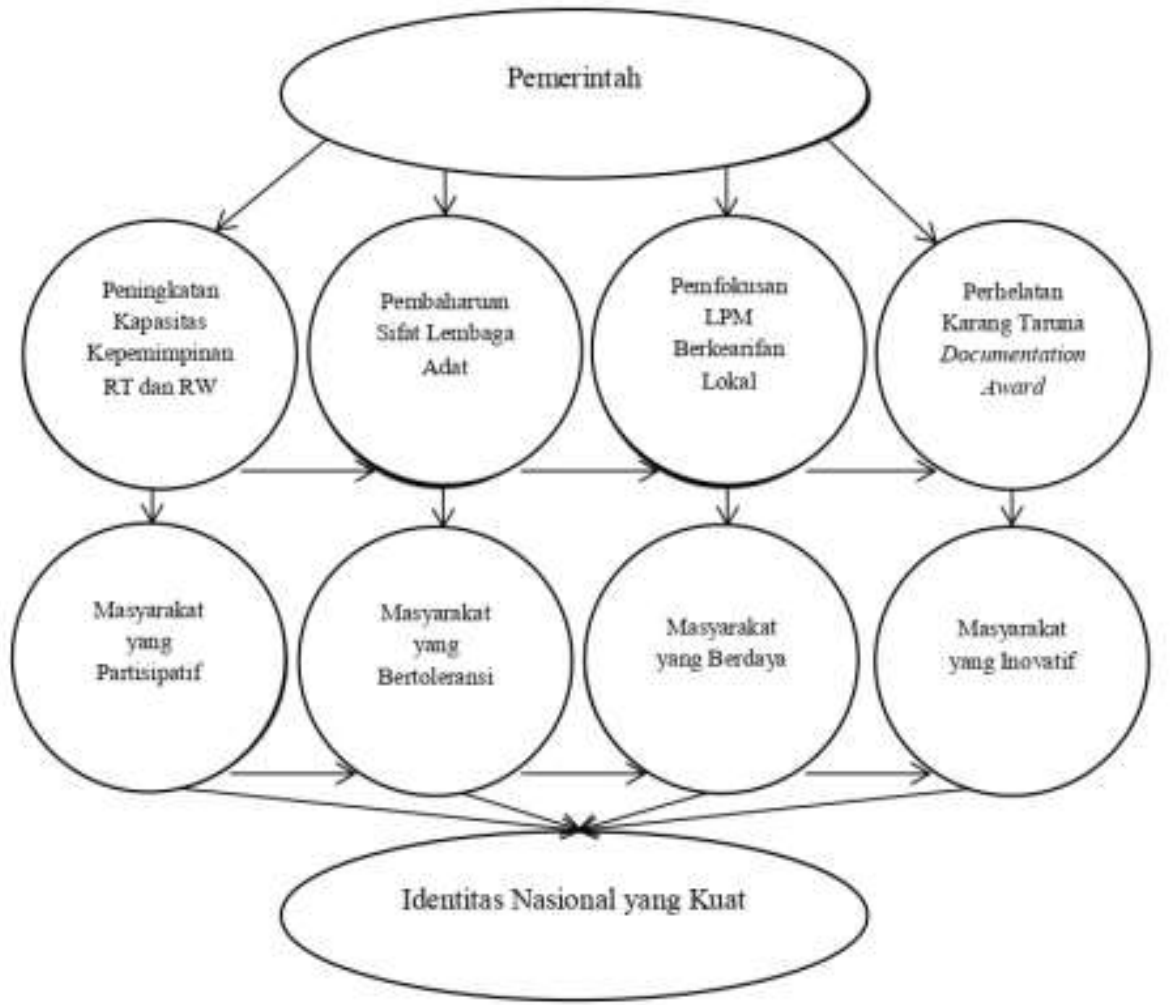

Sumber: Hasil Penelitian, 2021.

\section{a. Peningkatan Kapasitas Kepemimpinan RT dan RW}

Dalam penguatan identitas nasional, Rukun Tetangga (RT) dan Rukun Warga (RW) merupakan lembaga yang berbeda namun memiliki kesamaan tugas dan fungsi. RT merupakan Lembaga Kemasyarakatan yang dibentuk dan berasal dari masyarakat yang berdomisili di suatu lokasi tertentu (di wilayah RT itu sendiri). Sedangkan RW merupakan Lembaga Kemasyarakatan yang dibentuk dan berasal dari masyarakat setempat dalam hal ini adalah kumpulan beberapa RT dalam suatu lokasi tertentu. Kedua lembaga ini dalam membantu pemerintah memperkuat identitas nasional adalah dengan menggerakkan partisipasi masyarakat. Untuk meningkatkan hal tersebut maka diperlukan partisipasi masyarakat dengan semangat menjaga kerukunan antar warga walaupun memiliki perbedaan-perbedaan dalam suatu kehidupan bermasyarakat.

Peran RT dan RW dalam membangkitkan partisipasi masyarakat diperlukan suatu kepemimpinan yang mumpuni. Jika merujuk salah satu teknik kepemimpinan pemerintahan, maka ketua RT dan ketua RW perlu dibina oleh pemerintah dalam penguasaan teknik komunikatif. Teknik yang memiliki makna berupa apa yang diinginkan pemberi pesan sama dengan apa yang diterima penerima pesan. Artinya, ketua RT dan ketua RW dapat memberikan 
pesan pentingnya partisipasi masyarakat dalam memperkuat identitas nasional sehingga dipahami serta dijalankan oleh pribadi masing-masing masyarakat. Kelemahan teknik komunikatif yang tidak efektif tanpa komunikasi langsung dua arah akan tertutupi dengan kelebihan Lembaga Kemasyarakatan yang merupakan lembaga terdekat dengan masyarakat di seluruh Indonesia.

\section{b. Pembaharuan Sifat Lembaga Adat}

Lembaga Adat adalah suatu lembaga kemasyarakatan yang terbentuk karena sengaja didirikan maupun yang tak direncanakan/ secara sendirinya terbentuk di dalam masyarakat dengan wilayah dan hukum adat tertentu yang berlaku. Lembaga Adat memiliki hak dan wewenang untuk mengurus, mengatur, serta menyelesaikan segala persoalan kehidupan yang terjadi di dalam wilayahnya dengan berpedoman pada hukum adat serta adat istiadat yang berlaku.

Menganalisis hubungan peran Lembaga Adat dalam penguatan identitas nasional, sifat homogen yang kental tertanam pada lembaga ini dapat menjadi penghalang jika tidak dikelola dengan cara yang benar oleh pemerintah. Hal ini terjadi karena kehidupan bermasyarakat kontemporer saat ini tidak hanya terdiri oleh satu etnis dalam satu wilayah walaupun dengan adat yang kuat. Masyarakat pendatang yang memiliki etnis berbeda telah memasuki kehidupan bermasyarakat adat setempat. Maka, tidak jarang muncul aktivitas yang membentuk paguyuban yang berbau etnis di wilayah setempat.

Hal yang dapat dilakukan untuk mengelola aktivitas ini adalah merubah sifat Lembaga Adat yang mulanya bersifat homogen menjadi semi-homogen. Artinya, dalam lembaga tersebut akan dibentuk struktur baru berupa Seksi Nusantara yang dimana ketua dari seksi ini merupakan salah seorang dari anggota paguyubanpaguyuban etnis yang dipilih secara musyawarah. Hal ini dilakukan dengan maksud memunculkan bentuk solidaritas Suku, Agama, Ras, dan Antar Golongan (SARA) berupa tumbuhnya rasa urgenisitas eksistensi paguyuban atau transmigran dalam rasa empati mengembangkan adat ditempat mereka berpijak serta menimbulkan timbal balik pula terhadap rasa penghormatan terhadap paguyuban atau transmigran yang ada disana. Bahkan untuk daerah perkotaan yang notabenenya tidak kental lagi dengan adat, dapat dibentuk lembaga adat jika telah bersifat semi-homogenitas.

\section{c. Pemfokusan LPM Berkearifan Lokal}

$\begin{array}{lcr}\text { Lembaga } & \text { Pemberdayaan } & \text { Masyarakat } \\ \text { (LPM) } & \text { merupakan } & \text { Lembaga }\end{array}$ Kemasyarakatan yang bermitra kerja dengan pemerintah untuk menampung segala aspirasi masyarakat setempat serta mewujudkan harapannya dalam bidang perencanaan dan pelaksanaan pembangunan. Dalam kaitannya dengan identitas nasional, LPM mempunyai satu kesatuan dengan dua strategi sebelumnya untuk selanjutnya difokuskan pada pemberdayaan masyarakat dan penguatan identitas nasional.

LPM serta pemerintah melakukan pemberdayaan masyarakat melalui perencanaan dan pelaksanaan bernuansa kearifan lokal yang berguna untuk pelestarian sekaligus penguatan identitas nasional. LPM dapat membuat sebuah usaha yang menghasilkan produk utama berupa produk lokal setempat. Produk yang pembuatannya secara harfiah dikuasai oleh masyarakat asli setempat dapat dimobilisasi supaya masyarakat pendatang atau transmigran untuk 
menguasainya juga. Sehingga pembauran antar perbedaan identitas akan menguat menjadi masyarakat yang berdaya sekaligus beridentitas nasional.

\section{d. Perhelatan Karang Taruna Documentation Award}

Karang Taruna adalah wadah pengembangan bagi generasi muda. Lembaga kemasyarakatan yang satu ini terbentuk, tumbuh, serta berkembang karena kesadaran dan rasa tanggung jawab sosial dari masyarakat, oleh masyarakat, dan bagi masyarakat, dalam hal ini generasi muda yang ada di wilayah desa/kelurahan. Karang taruna bergerak dalam bidang usaha kesejahteraan sosial. Pada pelaksanaannya, lembaga kemasyarakatan ini berada di bawah binaan Kemensos. Dalam membina lembaga ini guna memperkuat identitas nasional, pemerintah perlu melakukan gebrakan dalam memobilisasi kemampuan ilmu pengetahuan dari para pemuda di tengah perkembangan teknologi internet saat ini.

Karang Taruna Documentation Award merupakan langkah yang dapat dilakukan oleh pemerintah dengan memanfaatkan media sosial guna membuat kompetisi nasional tingkat pemuda berupa kompetisi dokumentasi kreatif produk lokal yang ada di kelurahan atau desa masing-masing. Dengan hal ini pemuda dapat berinovasi mempromosikan produk lokal ke publik serta mendapat pembelajaran tersendiri dari kompetisi tersebut bahwasanya negara Indonesia merupakan negara yang kaya akan perbedaan dan dari perbedaan itu merupakan kesatuan yang utuh. Peran lembaga Rukun Tetangga (RT) dan Rukun Warga (RW), Lembaga Adat, dan Lembaga Pemberdayaan Masyarakat (LPM) yang dijalankan maksimal dengan langkah-langkah sebelumnya akan dapat menuntun pemuda berpartisipasi dalam program ini.

\section{Kesimpulan}

Identitas nasional Indonesia terdiri dari:

1) Teritorial seluruh wilayah seluas $8.647 .003,475 \mathrm{~km}^{2}$ yang terbagi dari luas daratan $1.993 .662,036 \mathrm{~km}^{2}$ dan luas lautan 6.653.341,439 $\mathrm{km}^{2}$;

2) Suku bangsa yang beragam dimana suku Jawa merupakan suku terbanyak dengan jumlah 95.217.022 penduduk;

3) Bahasa daerah yang beragam masih dituturkan oleh mayoritas penduduk dimana persentasenya sebesar $97,45 \%$; dan

4) Enam agama resmi yang dianut di Indonesia yakni: Islam, Hindu, Budha, Katolik, Kristen, serta Kong $\mathrm{Hu}$ Chu.

Dalam upaya memperkuat identitas nasional Indonesia melalui perencanaan pembangunan berbasis Lembaga Kemasyarakatan dilakukan melalui peningkatan kapasitas kepemimpinan Rukun Tetangga dan Rukun Warga, pembaharuan sifat Lembaga Adat, pemfokusan LPM berkearifan lokal, dan perhelatan Karang Taruna documentation award. Peran pemerintah melaksanakan kewajibannya dalam melakukan pembinaan Lembaga Kemasyarakatan merupakan kunci pertama. Selanjutnya, kunci kedua adalah peran masyarakat menanamkan kesadaran untuk meningkatkan partisipasi aktif mereka dalam Lembaga Kemasyarakatan. Lembaga kemasyarakatan bisa menjadi wadah yang ideal memperkuat identitas nasional Indonesia karena perannya dalam pemberdayaan masyarakat memiliki keunggulan sebagai lembaga yang terdekat dengan masyarakat di seluruh Indonesia. 
Lembaga Kemasyarakatan yang menghasilkan masyarakat yang partisipatif, bertoleransi, berdaya, serta inovatif dinilai telah menjadi satu kesatuan maksimal dalam penguatan identitas nasional Indonesia. 


\section{DAFTAR PUSTAKA}

Badan Pusat Statistik. (2020). Keadaan Ketenagakerjaan Indonesia Agustus 2020. Berita Resmi Statistik Nomor 86/11/Th. XXIII, 05 November 2020.Diunduh dari https://www.bps.go.id/pressrelease/ 2020/11/05/1673/agustus-2020-tingkat-pengangguran-terbuka--tpt-sebesar-7-07-persen.html.

Hadijoyo, Suryo Sakti dan Fahima Diah Anisa. (2019). Perencanaan Pembangunan Daerah: Suatu Pengantar. Depok: Rajawali Pers.

Kaelan dan Achmad Zubaidi. (2010). Pendidikan Kewarganegaraan. Yogyakarta: Paradigma.

Kaelan. (2013). Negara Kebangsaan Pancasila. Yogyakarta: Paradigma.

Kurniati, Dian. (2020). Efek Virus Corona: Duh, Jumlah Pengangguran Bertambah! Ini Data Terbaru BPS. Diakses dari https://news.ddtc.co.id/duh-jumlahpengangguran-bertambah-ini-dataterbaru-bps-25295.

Martono, Nanang. (2015). Metode Penelitian Sosial: Konsep-konsep Kunci. Jakarta: Rajawali Pers.

Muslim, Aziz. (2007). Pendekatan Partisipatif Dalam Pemberdayaan Masyarakat. Jurnal Aplikasi ilmuIlmu Agama, 8 (2), 89-103. Diundah dari http://digilib.uinsuka.ac.id/8286/1/AZIZ\%20MUSL IM\%20PENDEKATAN\%20PART ISIPATIF\%20DALAM\%20PEMB ERDAYAAN\%20MASY\%20ARA RAT.pdf.
Mustafa. (2014). Gerakan Membangun Bersama Masyarakat. Ciputat: Yayasan Masyarakat Indonesia Baru.

Na'im, Akhsan dan Hendry Syaputra. (2012). Kewarganegaraan, Suku Bangsa, Agama, dan Bahasa Sehari-hari Penduduk Indonesia Hasil Sensus Penduduk 2010. Diunduh dari https://www.bps.go.id/publication/2 012/05/23/55eca38b7fe0830834605 b35/kewarganegaraan-suku-bangsaagama-dan-bahasa-sehari-haripenduduk-indonesia.html.

Peraturan Menteri Dalam Negeri Nomor 5 Tahun 2007 tentang Pedoman Penataan Lembaga Kemasyarakatan.

Ramdhan, Muhammad dan Taslim Arifin. (2013). Aplikasi Sistem Informasi Geografis dalam Penilaian Proporsi Luas Laut Indonesia. Jurnal Ilmiah Geomatika, 19 (2), 141-146. Diunduh dari http:/jurnal.big.go.id/index.php/G M/article/view/208.

Rauf, Rahyunir dan Yusri Munaf. (2015). Lembaga Kemasyarakatan di Indonesia. Pekanbaru: Zanafa Publishing.

Ruslan, Idrus. (2014). 'Membangun' Nasionalisme Sebagai Solusi Untuk Mengatasi Konflik Sara Di Indonesia. Jurnal TAPIs, 10 (1), 118. Diunduh dari http://ejournal.radenintan.ac.id/inde x.php/TAPIs/article/view/1513. 
Soekanto, Soerjono. (2012). Sosiologi Suatu Pengantar. Jakarta: Rajawali Pers.

Syafiie, Inu Kencana. (2013). Ilmu Pemerintahan. Jakarta: Bumi Aksara.

Theresia, Aprilia. dkk. (2015). Pembangunan Berbasis Masyarakat. Bandung: Alfabeta. 